\title{
The Medical Risks of Obesity
}

\author{
Xavier Pi-Sunyer, MD ${ }^{1}$ \\ ${ }^{1}$ Division of Endocrinology, Diabetes and Nutrition, St. Luke's-Roosevelt Hospital Center, Columbia \\ University, New York, NY
}

\begin{abstract}
Obesity is at epidemic proportions in the United States and in other developed and developing countries. The prevalence of obesity is increasing not only in adults, but especially among children and adolescents. In the United States in 2003 to 2004, 17.1\% of children and adolescents were overweight, and $32.2 \%$ of adults were obese. Obesity is a significant risk factor for and contributor to increased morbidity and mortality, most importantly from cardiovascular disease (CVD) and diabetes, but also from cancer and chronic diseases, including osteoarthritis, liver and kidney disease, sleep apnea, and depression. The prevalence of obesity has increased steadily over the past 5 decades, and obesity may have a significant impact on quality-adjusted life years. Obesity is also strongly associated with an increased risk of all-cause mortality as well as cardiovascular and cancer mortality. Despite the substantial effects of obesity, weight loss can result in a significant reduction in risk for the majority of these comorbid conditions. Those comorbidities most closely linked to obesity must be identified to increase awareness of potential adverse outcomes. This will allow health care professionals to identify and implement appropriate interventions to reduce patient risk and mortality. A systematic search strategy was used to identify published literature between 1995 and 2008 that reported data from prospective longitudinal studies of obesity and comorbid medical conditions. This article will review evidence for significant associations of obesity with comorbidities to provide information useful for optimal patient management.
\end{abstract}

\section{Keywords}

cancer; cardiovascular disease; diabetes; obesity; cornorbidity; mortality

\section{Introduction}

Obesity, defined as a body mass index $(\mathrm{BMI}) \geq 30 \mathrm{~kg} / \mathrm{m}^{2},{ }^{1,2}$ is a medical condition encountered daily by physicians throughout the United States. The prevalence of obesity is increasing and reaching epidemic proportions (Figure 1), ${ }^{3}$ although recent data suggest that the prevalence is leveling off among children and adolescents. ${ }^{4}$ From 2003 to 2004 in the United States, 32.2\% of adults were obese and $17.1 \%$ of children and adolescents were overweight. ${ }^{5}$

A major concern for physicians who care for patients who are overweight or obese is the high risk of accompanying comorbid disorders, such as diabetes, cardiovascular disease (CVD), and cancer. An important need for primary care physicians is to identify these comorbidities and the resulting adverse outcomes. Awareness of the disorders with the strongest associations with

Correspondence: Xavier Pi-Sunyer, MD, Division of Endocrinology, Diabetes, and Nutrition, St. Luke's-Roosevelt Hospital Center, 1111 Amsterdam Avenue, Room 1020, New York, NY 10025. Tel: 212-523-4161 Fax: 212-523-4830 fxpI@columbia.edu.

Conflict of Interest Statement

Xavier Pi-Sunyer, MD discloses conflicts of interest with Amylin Pharmaceuticals, Arena Pharmaceuticals, Novartis, Novo Nordisk, Orexigen Therapeutics, and VIVUS, Inc. 
obesity is important to allow early diagnosis and treatment of these conditions, and to identify the patients most likely to benefit from weight loss. This will allow early identification and assessment of risk so that appropriate interventions can be implemented to reduce risk and mortality.

This article will review significant associations of obesity with comorbidities to provide the clinician with the information necessary to offer optimal patient management. A systematic search strategy was used to identify English language articles cited in PubMed between 1995 and 2008 that reported data from prospective, longitudinal studies of obesity and comorbid medical conditions. Relevant citations were comprehensively reviewed to determine those that confirmed a significant relationship between obesity and comorbid conditions.

\section{Overview of the Epidemiology of Obesity}

Numerous large, long-term epidemiological studies have shown that obesity is strongly associated with an increased risk of all-cause, cardiovascular, and cancer mortality (Figure 2). ${ }^{6}$ In the National Health and Nutrition Examination Study (NHANES) III, obesity was associated with an increased prevalence of type 2 diabetes, gallbladder disease, coronary heart disease (CHD), hypertension, osteoarthritis (OA), and high blood cholesterol among > 16000 participants. ${ }^{7}$ Results from other studies have shown a strong association between obesity and the prevalence of comorbid illnesses, health complaints, and physical disability. ${ }^{8-11}$ A 10 -year follow up from Nurses' Health Study (N > 121000) and the Health Professionals Follow-up Study ( $>$ 51000) evaluated the risk of diabetes, gallstones, and hypertension in obese (BMI $\geq 30 \mathrm{~kg} / \mathrm{m}^{2}$ ) men and women compared with those with a normal BMI. ${ }^{12}$ The risk of diabetes, gallstones, and hypertension was increased in women, while the risk of diabetes, gallstones, hypertension, heart disease, and stroke was increased in men. Based on the available data, The Obesity Society concluded that obesity is causally associated with functional impairment and reduced quality of life, serious disease, and greater mortality. ${ }^{13}$

The association between obesity and comorbid conditions, which will be discussed in the section that follows, is illustrated in Figure 3, where chronic conditions such as kidney disease, OA, cancer, diabetes, sleep apnea, nonalcoholic fatty liver disease (NAFLD), hypertension, and most importantly, CVD, are directly related to obesity. ${ }^{11,12}$ Further, many of these comorbidities also are directly associated with CVD.

Many of the epidemiological studies have been confirmed by observations that weight loss improves patient outcomes. The results from the Swedish Obesity Study showed that weight loss from bariatric surgery reduced most cardiovascular risk factors. ${ }^{11}$ An American Heart Association Committee also concluded that weight loss and physical activity could prevent and treat obesity-related CHD risk factors. ${ }^{14}$ Data reporting that a specific outcome is improved by weight loss will also be reviewed.

\section{Obesity and Comorbidity}

\section{Diabetes}

The long-term risk of type 2 diabetes increases significantly with increasing weight. In the Nurses' Health Study, the effect of weight change on the risk for clinical diabetes was evaluated in 114281 women. ${ }^{15}$ After adjusting for age, body weight was the major risk factor for diabetes during a 14-year follow-up. Among women with a 5- to 7.9-kg weight gain, the relative risk for diabetes was 1.9 and for those with an 8 - to $10.9-\mathrm{kg}$ weight gain, the relative risk was 2.7 . In contrast, a $5-\mathrm{kg}$ weight loss resulted in a $50 \%$ reduction in the risk of diabetes. 
Consistent with this observation, several studies have shown that weight loss is associated with a significant reduction in the risk of diabetes. ${ }^{16}$ In a prospective, 20-year study of 7176 British men, the rate of new diabetes was 11.4 per 1000 person-years among obese subjects versus 1.6 among normal-weight subjects $(P<0.0001)$, but the effect of weight change during a 5-year follow-up on the development of diabetes found a relative risk of 0.62 among those losing weight compared with 1.0 for stable weight and 1.76 among those gaining $>10 \%$ body weight $(P<0.0001)$. Similarly, a Health Technology Assessment that examined the effect of weight loss in patients with diabetes found significant improvement in the risk of developing diabetes. ${ }^{17}$ Long-term weight loss was also associated with a reduction in the risk of type 2 diabetes in the Diabetes Prevention Program. ${ }^{18}$ Thus, despite the known risk of type 2 diabetes associated with obesity, weight loss has the potential to improve outcomes.

Weight loss was also associated with improved diabetes control in the Look AHEAD (Action for Health in Diabetes) study ${ }^{19}$ Look AHEAD is a randomized trial of intensive lifestyle intervention versus usual support and education in 5145 patients with type 2 diabetes andBMI $>25 \mathrm{~kg} / \mathrm{m}^{2}$. The intensive group lost $8.6 \%$ of body weight compared with $0.7 \%$ in supportive group $(P<0.001)$. At 1 year, intensive intervention resulted in clinically significant weight loss in people with type 2 diabetes, which was associated with improved diabetes control and reduction in CVD risk factors and medication use.

\section{Cardiovascular Disease}

Obesity is an independent risk factor for CVD, defined as including CHD, myocardial infarction (MI), angina pectoris, congestive heart failure (CHF), stroke, hypertension, and atrial fibrillation. ${ }^{7,14}$ Overall, results from large prospective and observational studies confirm the marked adverse effects of obesity on CVD.

Numerous large-scale, long-term studies in the United States have investigated the role of obesity in CVD risk and on the development of CVD. The Multiethnic Study of Atherosclerosis evaluated the effects of obesity on CVD risk factors and on subclinical signs of CVD in 6814 participants who were free of CVD at baseline. ${ }^{20}$ Hypertension and diabetes as well as subclinical cardiovascular findings were more prevalent in obese $\left(B M I \geq 30 \mathrm{~kg} / \mathrm{m}^{2}\right.$ ) than nonobese participants. In addition, data collected from the original cohort of 5209 participants of the Framingham Heart Study over 44 years were used to evaluate the effect of obesity (BMI $\geq 30 \mathrm{~kg} / \mathrm{m}^{2}$ ) on the risk of CVD (angina, MI, CHD, or stroke), diabetes, hypertension, and hypercholesterolemia. ${ }^{21}$ During follow-up, the age-adjusted relative risk for CVD was 1.46 in men and 1.64 in women, and the age-adjusted relative risk for hypertension was even higher among obese men and women (2.21 and 2.75, respectively). In a separate analysis of the Framingham Heart Study, the lifetime risk of CVD was assessed among obese men and women with diabetes versus nonobese subjects. ${ }^{22}$ During a 30-year follow-up, the risk of CVD was $54.8 \%$ in normal-weight women versus $78.8 \%$ among obese women with diabetes and $78.6 \%$ versus $86.9 \%$ among normal and obese men with diabetes, respectively. ${ }^{22}$

Similar results have been obtained in studies performed outside of the United States. The International Day for the Evaluation of Abdominal Obesity (IDEA) study evaluated waist circumference, CVD, and diabetes mellitus in 168000 primary care patients in 63 countries.

${ }^{23}$ Overall, 24\% of men and 27\% of women were obese, and the risk of CVD and diabetes was strongly associated with BMI and waist circumference. Lastly, among 7176 British men followed for 20 years, the rate of major CVD was $24.9 / 1000$ in obese $\left(B M I \geq 30 \mathrm{~kg} / \mathrm{m}^{2}\right)$ subjects versus 13.9/1000 among normal-weight $\left(\mathrm{BMI}<25 \mathrm{~kg} / \mathrm{m}^{2}\right)$ subjects. ${ }^{16}$

Results from the Framingham Heart Study also showed that obesity increases the risk of atrial fibrillation. ${ }^{24}$ Among 5282 participants (of whom 55\% were women) without atrial fibrillation at baseline, subjects were classified as normal (BMI $<25 \mathrm{~kg} / \mathrm{m}^{2}$ ), overweight, and obese (BMI 
$\geq 30 \mathrm{~kg} / \mathrm{m}^{2}$ ). During a mean follow-up of 13.7 years, a $4 \%$ increase in risk of atrial fibrillation/ 1-unit increase in BMI was observed in men and women after adjustment for cardiovascular risk factors. Compared with normal-weight individuals, in obese subjects the hazard ratio for atrial fibrillation was 1.52 for men and 1.46 for women.

Among 111847 patients with non-ST-segment myocardial infarction (NSTEMI) who were included in the CRUSADE registry, ${ }^{25}$ excess BMI was also strongly associated with an earlier age of first NSTEMI. The registry collected data from January 2001 to January 2007 in highrisk patients with unstable angina and NSTEMI. Extreme obesity (BMI $>40 \mathrm{~kg} / \mathrm{m}^{2}$ ) had the strongest association with age at first MI after adjustment for baseline factors. After adjustment for baseline demographic data, cardiac risk factors, and medications, the first NSTEMI occurred 3.5, 6.8, 9.4, and 12 years $(P<0.0001)$ earlier with increasing adiposity (BMI 25.1$30 \mathrm{~kg} / \mathrm{m}^{2}, 30.1-35 \mathrm{~kg} / \mathrm{m}^{2}, 35.1-40 \mathrm{~kg} / \mathrm{m}^{2}$, and $>40 \mathrm{~kg} / \mathrm{m}^{2}$, respectively).

Hypertension, a risk factor for CVD, is related to obesity. An analysis from the Women's Health Study found a significant association between obesity, the development of hypertension, and diabetes. ${ }^{26}$ In this analysis of 38172 women who were free of diabetes and CVD at baseline with a mean 10.2 years of follow-up, the age-adjusted incidence rate/1000 of diabetes in obese women $\left(\mathrm{BMI} \geq 30 \mathrm{~kg} / \mathrm{m}^{2}\right)$ was 7.58 among normotensive patients $(120 / 75)$ versus $20.53 \mathrm{among}$ hypertensive patients. Further, a significant association between BMI and hypertension was observed in a prospective study from Norway, the Nord-Trondelag Health Study. ${ }^{27}$ Among> 15900 women and > 13800 men at least 20 years old without hypertension, diabetes, or CVD at baseline, the risk for hypertension was increased $\geq 1$.4-fold among men and women whose BMI increased from baseline compared with those who maintained a stable BMI.

\section{Metabolic Syndrome}

A combination of commonly associated cardiovascular risk factors is known as metabolic syndrome (MetS). Metabolic syndrome represents a group of cardiometabolic risk factors that include abdominal obesity combined with elevated blood pressure, fasting plasma glucose, and triglycerides, and reduced high-density lipoprotein cholesterol levels. Metabolic syndrome is associated with an increased risk of cardiovascular mortality. ${ }^{28}$ Guidelines for the diagnosis and management of MetS are available from a number of professional organizations including the American Heart Association and the International Union of Angiology. ${ }^{29,30}$

As discussed previously, abdominal obesity, a key part of the constellation of risk factors for MetS, is strongly associated with the risk of diabetes. ${ }^{31,32} \mathrm{An}$ analysis of the associations between risk factors for MetS in 2735 participants from the Dallas Heart Study showed that higher BMI was significantly associated with MetS in both diabetic and nondiabetic patients. ${ }^{31}$ In a prospective cohort study that examined the association between MetS and type 2 diabetes among 4022 patients with atherosclerosis, abdominal obesity was the component most strongly associated with the risk of type 2 diabetes. ${ }^{32}$ Data from 9 European studies were examined to determine the association between MetS and abdominal adiposity in $>15000$ men and women. ${ }^{28}$ The definition of MetS was satisfied in $41 \%$ of men and 37.9\% of women, and those with MetS were more often obese and had a higher prevalence of diabetes than nonobese participants. A prospective study of 3051 elderly men with diabetes or CHD also found that obesity and physical inactivity as well as cigarette smoking and high carbohydrate diet were significantly associated with a greater risk of MetS. ${ }^{33}$

In contrast, weight reduction alone or combined with lifestyle intervention is associated with a significant reduction in the prevalence of MetS. ${ }^{34,35}$ The prevalence of MetS and abdominal obesity was significantly reduced from $74 \%$ to $58 \%$ in a lifestyle intervention group versus to $67.7 \%$ in a standard care group $(P=0.025) .{ }^{34} \mathrm{In}$ a separate study, a moderate 8 -kg reduction 
in weight after 1 year resulted in a significant $(P<0.05)$ reduction in the prevalence ofMetS from $35 \%$ to $27 \% .35$

\section{Cancer}

A number of large-scale, prospective studies have confirmed a significant association between obesity and cancer. The strongest association is between an elevated BMI and cancer risk. A prospective cohort study in the United States found a significant association between obesity and cancer. ${ }^{36}$ This prospective study involved $>900000$ subjects from the American Cancer Prevention Study II who were free from cancer in 1982 and had a mean follow up of 16 years. Among those with a BMI $\geq 40 \mathrm{~kg} / \mathrm{m}^{2}$, mortality from all causes of cancer was $52 \%$ higher in men and $62 \%$ higher in women compared with those with a normal BMI. Body mass index was also significantly associated with higher rates of death due to cancer of the esophagus, colon and rectum, liver, gallbladder, pancreas, kidney, non-Hodgkin lymphoma, and multiple myeloma.

In the Million Women Study from the United Kingdom, increasing BMI was associated with a significant increase in risk for 10 out of 17 of the most common types of cancer. ${ }^{37}$ Over 1.2 million UK women, aged 50 to 64 years during 1996 to 2001, were recruited into the Million Women Study and followed for a mean of 5.4 years for cancer incidence and 7 years for cancer mortality. Increasing BMI was associated with an increased incidence of all cancers combined in addition to endometrial cancer, adenocarcinoma of the esophagus, kidney cancer, leukemia, multiple myeloma, pancreatic cancer, non-Hodgkin lymphoma, ovarian cancer, breast cancer in postmenopausal women, and colorectal cancer in premenopausal women (Figure 4).

A prospective study evaluated the effect of BMI and weight gain on prostate cancer incidence and mortality among 287700 men in the NIH-AARP Diet and Health Study. ${ }^{38}$ During a mean follow-up of 5 to 6 years, the relative risk for mortality from prostate cancer was 1.46 and 2.12 for a BMI $\geq 30 \mathrm{~kg} / \mathrm{m}^{2}$ and $\geq 35 \mathrm{~kg} / \mathrm{m}^{2}$, respectively. In a separate study of $69991 \mathrm{men}$, the risk of high-grade nonmetastatic and metastatic prostate cancer was increased with obesity (1.2and 1.5-fold, respectively), and the risk of high-grade nonmetastatic cancer was reduced to 0.58 with > 11-lb weight loss. ${ }^{39}$

In the Health Professionals Follow-up Study, a significant association between obesity and colon cancer was observed in men. ${ }^{40}$ This 18 -year, prospective follow-up study of 46349 men who were cancer-free at baseline found a multivariate hazard ratio (HR) for colon cancer was increased at a BMI $>22.5 \mathrm{~kg} / \mathrm{m}^{2}$, but was highest $(\mathrm{HR}, 2.29)$ at a BMI $>30 \mathrm{~kg} / \mathrm{m}^{2}$. An estimated $30 \%$ of all colon cancer cases were attributed to overweight and obesity.

Pischon et al ${ }^{41,42}$ evaluated the association between the risk of colon and rectal cancer and renal cell carcinoma and body weight in the European Prospective Investigation into Cancer and Nutrition (EPIC) study. More than 368000 men and women who were cancer-free at baseline were followed for a mean of 6.1 years in the EPIC Study. Body weight and BMI ( $\geq$ $29.4 \mathrm{~kg} / \mathrm{m}^{2}$ ) were significantly associated with the risk of colon cancer in men but not women (relative risk [RR], 1.55; $P=0.006)$. Among 348500 men and women with a 6-year followup, the RR for renal cell carcinoma associated with increased BMI in women was $2.25(P=$ $\left.0.009 ; \mathrm{BMI} \geq 29 \mathrm{~kg} / \mathrm{m}^{2}\right)$ but no significant increase was observed for men (RR, $\left.1.22 ; P=0.51\right)$.

\section{Arthritis and Disability}

Osteoarthritis has a major impact on patient mobility, disability, lost productivity, and patients may become disabled from OA early in life. ${ }^{43,44}$ Obesity is strongly associated with an increased risk of OA of the knee but only a moderate association with OA of the hip has been 
found. ${ }^{45}$ Because OA strongly impacts patient lifestyle and function, it is important to recognize this effect of obesity and the potential need for weight loss and rehabilitation.

The relationship between OA of the hip and knee and obesity was examined in The Rotterdam Study. ${ }^{45}$ Radiographic confirmation of OA was established in 3585 participants at baseline, and patients were followed for a mean of 6.6 years. A BMI $>27 \mathrm{~kg} / \mathrm{m}^{2}$ was associated with a 3.3-fold greater risk of OA and progression of OA of the knee but not the hip. In a longitudinal study of 715 women in the Chingford population over 4 years, mean age 54 years at baseline, those in the top BMI tertile had an increased risk of knee OA compared with women in lower BMI tertiles. ${ }^{46}$ In The Framingham Heart Study, the effect of obesity on the increased risk of knee OA was determined in elderly patients without knee OA at baseline. ${ }^{47}$ Among 598 patients who developed OA over a 1O-year follow-up, the risk for OA was increased by 1.6 for each 5 -unit increase of BMI.

The association between obesity and OA of the knee is thus widely recognized. A number of prospective studies have examined the relationship between obesity and disability in patients with knee OA. ${ }^{48-52}$ A prospective cohort study of 5784 participants at least 50 years old was conducted to examine the effect of obesity on knee pain and disability. ${ }^{49}$ Obesity accounted for a substantial proportion of severe disabling knee pain in this cohort, and the authors concluded that health interventions to avoid obesity would have a major impact on improving disability associated with knee OA. Another cross-sectional study of 3664 participants $>25$ years old found that obesity was associated with a higher risk of OA of the hip or knee, chronic pain, and a mobility disability. ${ }^{52}$ In 56 obese adults, ${ }^{51}$ knee OA was significantly associated with reduced exercise capacity, ambulatory capacity, and quality of life.

Importantly, weight loss has been shown to significantly improve signs and symptoms of OA and improve disability and function in obese patients. ${ }^{53-58}$ A meta-regression analysis that included 4 trials including a total of 454 patients was conducted on the effect of weight loss on OA. ${ }^{53}$ Mean baseline BMI ranged from 29 to $36 \mathrm{~kg} / \mathrm{m}^{2}$ in each of 5 intervention groups, and weight loss ranged from 1.7 to $6.7 \mathrm{~kg}$ over 6 weeks to 18 months. Modest weight loss $(5.1 \%)$ improved physical disability among patients with knee OA. A randomized study of 87 obese (BMI $\geq 30 \mathrm{~kg} / \mathrm{m}^{2}$ ) adults at least 60 years old with symptomatic knee OA was also undertaken to evaluate the effect of weight loss intervention. ${ }^{57}$ At 6 months, those randomized to intervention had lost a mean of $8.7 \%$ of body weight compared with no weight loss in the control group. Functional status was significantly $(P<0.05)$ improved in the intervention group with greater improvements observed with more weight loss. Others have found significant improvements in function and pain with weight loss and/or exercise among patients with knee OA. ${ }^{55,56,58}$ Thus, recognition of the impact of obesity among patients with knee OA offers an opportunity to significantly improve associated disability and pain by encouraging weight loss.

\section{Gallbladder Disease}

Gallbladder disease is a common cause of hospitalization, especially among women, and has a considerable impact on health care costs. ${ }^{59}$ An epidemiologic study from the National Health Service in England and Scotland found a significant association between obesity and gallbladder disease among women. ${ }^{59}$ In this study, data for 1.3 million women (mean age, 56 years), representing 7.8 million person-years of follow-up, were evaluated. After adjusting for age, socioeconomic status, and other factors, women with higher BMI at study entry were more likely to be admitted and spend more days in the hospital for gallbladder disease. For each 1000 person-years of follow-up, women with BMI in the lowest BMI category (18.5-24.9 kg/ $\mathrm{m}^{2}$ ) spent a mean of 16.5 days hospitalized versus 44 days for women in the obese category (BMI $30-39.9 \mathrm{~kg} / \mathrm{m}^{2}$ ). Overall, $25 \%$ of hospital days for gallbladder disease were attributed to obesity. 
In a prospective evaluation from the Health Professionals Follow-up Study, the association between abdominal obesity and the incidence of symptomatic gallstone disease was determined in a cohort of 29847 men who were free of prior gallstone disease and who provided complete data on waist and hip circumferences. ${ }^{60}$ Men with BMI $\geq 28.5 \mathrm{~kg} / \mathrm{m}^{2}$ had a 2.49 -fold greater risk of gallstones compared with men with a normal BMI $\left(<22.2 \mathrm{~kg} / \mathrm{m}^{2}\right)$ Similar findings were observed in the Swedish Twin Registry Study. ${ }^{61}$ The Swedish Twin Registry study assessed the effects of overweight and obesity (BMI $>30 \mathrm{~kg} / \mathrm{m}^{2}$ ) on symptomatic gallstones in 58400 participants. Overweight and obesity were both associated with a significant increase in the risk of symptomatic gallstones ( $\mathrm{OR}=1.86$ and 3.38 , respectively).

\section{Acute Pancreatitis}

Acute pancreatitis is closely associated with obesity, and a number of studies have shown that obesity increases the severity of and mortality from acute pancreatitis. ${ }^{62-65}$ Obesity is a primary risk factor for local complications, organ failure, and death from acute pancreatitis.

In a meta-analysis of 5 studies including a total of 739 patients, obesity $\left(B M I \geq 30 \mathrm{~kg} / \mathrm{m}^{2}\right.$ ) was identified as a risk factor for the development of local and systemic complications in acute pancreatitis and was also associated with increased mortality. ${ }^{64}$ Among these patients from the 5 studies, severe acute pancreatitis was significantly associated with obesity (OR 2.9, 95\% CI 1.8-4.6). Among these obese patients, significantly more systemic (OR 2.3 , 95\% CI 1.4-3.8) and local complications occurred (OR 3.8, 95\% CI 2.4-6.6), and mortality was higher (OR 2.1, 95\% CI 1.0-4.8).

\section{Nonalcoholic Fatty Liver Disease}

Nonalcoholic fatty liver disease (NAFLD) represents a spectrum of disorders that range from steatosis to nonalcoholic steatohepatitis and ultimately cirrhosis and hepatocellular carcinoma. ${ }^{66}$ Nonalcoholic fatty liver disease is associated with obesity, dyslipidemia, hypertension, and insulin resistance, components of the MetS that increase cardiovascular risk. ${ }^{67}$ It affects approximately $15 \%-30 \%$ of the general population, and has a prevalence of approximately $70 \%$ in people with type 2 diabetes. ${ }^{67}$

Studies have indentified obesity as a predictor of NAFLD. ${ }^{68-70}$ In a multivariate analysis among 832 Chilean participants, the primary variable associated with NAFLD was BMI > 26.9 $\mathrm{kg} / \mathrm{m}^{2.68}$ The diagnosis of NAFLD was based on ultrasound and no history of alcohol abuse or hepatitis $\mathrm{C}$ infection. Multivariate analysis found that obesity was significantly and independently associated with NAFLD with odds ratio of 6.2. In a cross-sectional study of 326 Israelis who participated in a National Health survey, the prevalence of NAFLD was 30\%; NAFLD was more common in men (38\%) than in women (21\%), and obesity (BMI $\geq 30 \mathrm{~kg}$ / $\mathrm{m}^{2}$ ) was independently associated with NAFLD (odds ratio 2.9). ${ }^{69}$ A study of 218 nonsmoking, healthy men found that 24 met criteria for NAFLD. ${ }^{70}$ Lack of fitness and BMI $\geq 30 \mathrm{~kg} / \mathrm{m}^{2}$ were significantly $(P<0.001)$ and independently associated with NAFLD.

Increased physical activity and bariatric surgery in selected cases may be effective therapy for NAFLD. ${ }^{71,72}$ Although evidence is limited, weight loss may be beneficial for reducing the risk of NAFLD in obese patients. ${ }^{71}$

\section{Pulmonary Complications}

Obstructive sleep apnea (OSA) potentially results in a number of complications including pulmonary hypertension, right heart failure, drug-resistant hypertension, stroke, and arrhythmias. ${ }^{73-78}$ Obstructive sleep apnea is characterized by upper airway obstruction that occurs as repetitive episodes during sleep. ${ }^{74}$ Among the typical features of OSA are loud snoring, fragmented sleep, repetitive hypoxemia/hypercapnia, daytime sleepiness, and 
cardiovascular complications. Although the prevalence of OSA is $2 \%$ to $3 \%$ among middleaged women and $4 \%$ to $5 \%$ among middle-aged men, the prevalence among obese patients is $>30 \%$ and among the morbidly obese ranges from $50 \%$ to $98 \% .{ }^{75-77}$ Thus, obesity is the most important risk factor for the development of OSA, where $60 \%$ to $90 \%$ of adults are overweight, and the relative risk in obese patients (BMI $\left.>29 \mathrm{~kg} / \mathrm{m}^{2}\right)$ is $\geq 10 .{ }^{74}$

The independent association between sleep-disordered breathing and weight gain was evaluated in a population-based, prospective study of 690 randomly selected residents of Wisconsin. ${ }^{76}$ Participants had a mean age of 46 years, a mean baseline BMI of $29-30 \mathrm{~kg} / \mathrm{m}^{2}$, and were evaluated twice at 4-year intervals. A $10 \%$ weight gain predicted a $32 \%$ increase in the apnea-hypopnea index and a 6-fold increase in the odds of developing moderate-to-severe sleep-disordered breathing.

Similarly, the effect of weight gain on sleep-disordered breathing was determined in a prospective study of 2968 men and women in the United States. ${ }^{77}$ Baseline mean BMI was approximately $29 \mathrm{~kg} / \mathrm{m}^{2}$, mean age was 62 years, and participants were examined at baseline and 5 years. An increased number of respiratory events was associated with weight increases. Men with a 10-kg increase in weight had 5.21-fold increased risk of developing > 15 events/ hour and women had a 2.5 -fold increased risk.

A reduction in OSA was observed in The Swedish Obesity Study among patients with diabetes who lost weight. ${ }^{78}$ This study evaluated 1729 patients with a baseline BMI $>40 \mathrm{~kg} / \mathrm{m}^{2}$ undergoing bariatric surgery and 1748 given conservative medical therapy as the control group. A significant $(P<0.001)$ reduction in symptoms of OSA was observed among the bariatric surgery group at 2 years including apnea ( $24 \%$ to $8 \%$ ), snoring ( $44.5 \%$ to $10.8 \%$ ), and daytime sleepiness ( $25.8 \%$ to $12.7 \%$ ). Those with a mean $31 \%$ weight loss had a 2 - to 13 -fold decrease in the risk of developing new OSA, and those with OSA were 2.5 to 7 times less likely to report continuing OSA symptoms.

\section{Depression}

An association between obesity and major depressive disorder (MDD) has long been recognized although a causal association is uncertain. Importantly, many antidepressant drugs are associated with weight gain. The National Epidemiologic Survey on Alcohol and Related Conditions evaluated the relationship between BMI and psychiatric disorders in 41654 respondents. ${ }^{79}$ Among participants, BMI was significantly associated with mood, anxiety, and personality disorders. The odds ratio for a psychiatric disorder was 1.21- to 2.08-fold greater among obese (BMI $30-39.9 \mathrm{~kg} / \mathrm{m}^{2}$ ) and extremely obese (BMI $\geq 40 \mathrm{~kg} / \mathrm{m}^{2}$ ) subjects, and the odds ratio for a lifetime prevalence of MDD was 1.53 and 2.02 among obese and extremely obese compared with normal weight subjects.

Others have found similar results. The 2006 Behavioral Risk Factor Surveillance System (N $=217379$ ) found that adults with current depression or a lifetime diagnosis of depression or anxiety were significantly more likely to have unhealthy behaviors including smoking, obesity, physical inactivity, binge drinking, and heavy drinking. ${ }^{80}$ The adjusted odds ratio for depression and obesity (BMI $\geq 30 \mathrm{~kg} / \mathrm{m}^{2}$ ) was 1.6 vs 1 for nonobese subjects, and the odds ratio increased with increasing severity of MDD. Among 4641 middle-aged women, MDD was strongly and consistently associated with obesity, lower physical activity, and among the obese, higher caloric intake. ${ }^{81}$ The prevalence of moderate or severe MDD increased from $6.5 \%$ with a BMI $<25 \mathrm{~kg} / \mathrm{m}^{2}$ to $25.9 \%$ with a BMI $>35 \mathrm{~kg} / \mathrm{m}^{2}$. The prevalence of obesity increased from $25.4 \%$ to $57.8 \%$ among those with no MDD versus those with moderate-tosevere MDD. The odds ratio for having MDD was 4.4 for a BMI of 30 to $35 \mathrm{~kg} / \mathrm{m}^{2}$ and 4.95 for a BMI of $\geq 35 \mathrm{~kg} / \mathrm{m}^{2}$. Using standard criteria for MDD, the odds ratios were 1.92 for a BMI of 25 to $30 \mathrm{~kg} / \mathrm{m}^{2}, 2.92$ for $20-35 \mathrm{~kg} / \mathrm{m}^{2}$, and 5.72 for a BMI of $\geq 35 \mathrm{~kg} / \mathrm{m}^{2}$. 
Despite the absence of a clear causal relationship between obesity and MDD, an awareness of this relationship and the opportunity to improve depression and quality of life by recommending appropriate weight loss interventions is needed.

\section{The Impact of Obesity on Mortality}

The net impact of the increased burden of disease associated with obesity is increased mortality, which is well established in this population. An extensive number of epidemiological studies have established a significant increase in cardiovascular and non cardiovascular mortality associated with obesity (Table 1). Overall, large-scale studies such the Nurses' Health Study, NHANES, Women's Health Initiative Observational Study, American Cancer Society Prevention studies, and others have documented the adverse effects of obesity on mortality from CVD, cancer, and other comorbidities. ${ }^{6,82-89} \mathrm{An}$ increase in years of life lost was found among obese versus nonobese subjects in an analysis of the NHANES database. ${ }^{90}$ Overall, years of life lost were 1 to 9 for those with low BMI $\left(<17-19 \mathrm{~kg} / \mathrm{m}^{2}\right)$ compared with 9 to 13 for those with a high BMI $\left(\geq 35 \mathrm{~kg} / \mathrm{m}^{2}\right)$.

Importantly, studies of patients undergoing gastric bypass surgery for morbid obesity have demonstrated significant reductions in mortality with substantial weight loss. ${ }^{91,92}$ Adams ${ }^{91}$ reported a retrospective cohort study of mortality in 7925 surgical patients and 7925 severely obese control subjects who were matched for age, sex, and BMI. During a mean follow-up of 7.1 years, all-cause mortality decreased by $40 \%$ (57.1 to 37.6/10 000 patient-years), and mortality decreased by $56 \%$ for CAD, $92 \%$ for diabetes, and $60 \%$ for cancer $(P<0.01$ for each). The Surgical Obesity Study was a prospective evaluation of gastric surgery $(n=2010)$ or conventional treatment $(\mathrm{n}=2037)$ of patients with morbid obesity. ${ }^{92}$ Overall mortality was reported after 10.9 years of follow-up, where average weight change was $2 \%$ in the control group and $14 \%$ to $25 \%$ in the surgery group depending on the procedure. The adjusted hazard ratio for mortality was $0.71(P=0.01)$ in the surgery group versus the control group.

\section{Summary}

Obesity is at epidemic proportions in the United States and other developed countries, but, importantly, even in developing countries. Large, high-quality longitudinal or prospective studies have confirmed that obesity is a significant risk factor for and contributor to increased morbidity and mortality, primarily from CVD and diabetes, but also from cancer and other acute and chronic diseases, including osteoarthritis, liver and kidney disease, sleep apnea, and depression (Figure 3). For the majority of these comorbid conditions, weight loss can result in a significant reduction in risk.

The economic costs of obesity are substantial. A model based on NHANES and the Framingham Heart Study was used to assess the lifetime health and economic consequences of obesity. ${ }^{93}$ The analysis showed substantial effects on lifetime health and economic consequences of obesity, and the authors suggested that significant benefits could be expected from interventions to prevent or reduce obesity. ${ }^{93}$ Disease risks and costs increased with increasing BMI. For instance, the risk of hypertension was 2-fold higher and diabetes was 3fold higher among 45 - to 54-year-old obese men compared with nonobese men. ${ }^{93}$ Lifetime medical costs increased incrementally with increased BMI and age by approximately 2 -fold for each group. Obesity also has a significant impact on quality-adjusted life years and reduces years oflife. ${ }^{90,93,94}$ In an analysis of quality-adjusted life years, obese men and women lost 1.9 million and 3.4 million quality-adjusted life years and experienced lower health-related quality of life compared with normal weight subjects. ${ }^{94}$ A model of the economic costs of obesity found a substantial impact could be reduced with effective measures to prevent weight gain. ${ }^{93}$ 
Recognition of the association between obesity and comorbidities is critical for patient diagnosis and management by primary care physicians. Physicians need to be aware of comorbidities and their implications for outcomes and patient management of the obese patient. Global efforts to control obesity and minimize factors that contribute to obesity are essential to improving health status and life expectancy worldwide.

\section{Acknowledgments}

The author would like to acknowledge the assistance of Richard S. Perry, PharmD in the preparation of this manuscript, which was funded by Amylin Pharmaceutics, Inc.

\section{References}

1. National Heart, Lung, and Blood Institute. Clinical guidelines on the identification, evaluation, and treatment of overweight and obesity in adults. http://www.nhlbi.nih.gov/guidelines/obesity/ ob_home.htm.

2. World Health Organization. Physical status: the use and interpretation of anthropometry. Report of a WHO Expert Committee. World Health Organ Tech Rep Ser 1995;854:1-452. [PubMed: 8594834]

3. Centers for Disease Control (CDC). BRFSS, Behavioral Risk Factor Surveillance System Survey Data, Atlanta, Georgia: US Department of Health and Human Services. http://www.cdc.gov/brfss.

4. Ogden CL, Carroll MD, Flegal KM. High body mass index for age among US children and adolescents, 2003-2006. JAMA 2008;299(20):2401-2405. [PubMed: 18505949]

5. Ogden CL, Carroll MD, Curtin LR, McDowell MA, Tabak CJ, Flegal KM. Prevalence of overweight and obesity in the United States, 1999-2004. JAMA 2006;295(13):1549-1555. [PubMed: 16595758]

6. Calle EE, Thun MJ, Petrelli JM, Rodriguez C, Heath CW Jr. Body-mass index and mortality in a prospective cohort of U .S. adults. N Engl J Med 1999;341(15):1097-1105. [PubMed: 10511607]

7. Must A, Spadano J, Coakley EH, Field AE, Colditz G, Dietz WH. The disease burden associated with overweight and obesity. JAMA 1999;282(16):1523-1529. [PubMed: 10546691]

8. Luo W, Morrison H, de Groh M, et al. The burden of adult obesity in Canada. Chronic Dis Can 2007;27 (4):135-144. [PubMed: 17623559]

9. Kress AM, Hartzel MC, Peterson MR. Burden of disease associated with overweight and obesity among U.S. military retirees and their dependents, aged 38-64, 2003. Prey Med 2005;41(1):63-69.

10. Peytremann-Bridevaux I, Santos-Eggimann B. Health correlates of overweight and obesity in adults aged 50 years and over: results from the Survey of Health, Ageing and Retirement in Europe (SHARE). Obesity and health in Europeans aged > or $=50$ years. Swiss Med Wkly 2008;138(17-19): 261-266. [PubMed: 18481232]

11. Rydén A, Torgerson JS. The Swedish Obese Subjects Study—what has been accomplished to date? Surg Obes Relat Dis 2006;2(5):549-560. [PubMed: 17015211]

12. Field AE, Coakley EH, Must A, et al. Impact of overweight on the risk of developing common chronic diseases during a 10-year period. Arch Intern Med 2001;161(13):1581-1586. [PubMed: 11434789]

13. Allison DB, Downey M, Atkinson RL, et al. Obesity as a disease: a white paper on evidence and arguments commissioned by the Council of the Obesity Society. Obesity (Silver Spring) 2008;16(6): 1161-1177. [PubMed: 18464753]

14. Klein S, Burke LE, Bray GA, et al. American Heart Association Council on Nutrition, Physical Activity, and Metabolism. Clinical implications of obesity with specific focus on cardiovascular disease: a statement for professionals from the American Heart Association Council on Nutrition, Physical Activity, and Metabolism: endorsed by the American College of Cardiology Foundation. Circulation 2004;110(18):2952-2967. [PubMed: 15509809]

15. Colditz GA, Willett WC, Rotnitzky A, Manson JE. Weight gain as a risk factor for clinical diabetes mellitus in women. Ann Intern Med 1995;122(7):481-486. [PubMed: 7872581]

16. Wannamethee SG, Shaper AG, Walker M. Overweight and obesity and weight change in middle aged men: impact on cardiovascular disease and diabetes. J Epidemiol Community Health 2005;59(2): 134-139. [PubMed: 15650145] 
17. Avenell A, Broom J, Brown TJ, et al. Systematic review of the long-term effects and economic consequences of treatments for obesity and implications for health improvement. Health Technol Assess 2004;8(21):1-182.

18. Fujimoto WY, Jablonski KA, Bray GA, et al. Diabetes Prevention Program Research Group. Body size and shape changes and the risk of diabetes in the diabetes prevention program. Diabetes 2007;56 (6):1680-1685. [PubMed: 17363740]

19. Look AHEAD Research Group. Pi-Sunyer X, Blackburn G, Brancati FL, et al. Reduction in weight and cardiovascular disease risk factors in individuals with type 2 diabetes: one-year results of the look AHEAD trial. Diabetes Care 2007;30(6):1374-1383. [PubMed: 17363746]

20. Burke GL, Bertoni AG, Shea S, et al. The impact of obesity on cardiovascular disease risk factors and subclinical vascular disease: the Multi-Ethnic Study of Atherosclerosis. Arch Intern Med 2008;168(9):928-935. [PubMed: 18474756]

21. Wilson PW, D'Agostino RB, Sullivan L, Parise H, Kannel WB. Overweight and obesity as determinants of cardiovascular risk: the Framingham experience. Arch Intern Med 2002;162(16): 1867-1872. [PubMed: 12196085]

22. Fox CS, Pencina MJ, Wilson PW, Paynter NP, Vasan RS, D' Agostino RB Sr. Lifetime risk of cardiovascular disease among individuals with and without diabetes stratified by obesity status in the Framingham heart study. Diabetes Care 2008;31(8):1582-1584. [PubMed: 18458146]

23. Balkau B, Deanfield JE, Després JP, et al. International Day for the Evaluation of Abdominal Obesity (IDEA): a study of waist circumference, cardiovascular disease, and diabetes mellitus in 168,000 primary care patients in 63 countries. Circulation 2007;116(17):1942-1951. [PubMed: 17965405]

24. Wang TJ, Parise H, Levy D, et al. Obesity and the risk of new-onset atrial fibrillation. JAMA 2004;292 (20):2471-2477. [PubMed: 15562125]

25. Madala MC, Franklin BA, Chen AY, et al. Obesity and Age of First Non-ST-Segment Elevation Myocardial Infarction. J Am Coll Cardiol 2008;52(12):979-985. [PubMed: 18786477]

26. Conen D, Ridker PM, Mora S, Buring JE, Glynn RJ. Blood pressure and risk of developing type 2 diabetes mellitus: the Women's Health Study. Eur Heart J 2007;28(23):2937-2943. [PubMed: 17925342]

27. Drøyvold WB, Midthjell K, Nilsen TI, Holmen J. Change in body mass index and its impact on blood pressure: a prospective population study. Int J Obes (Land) 2005;29(6):650-655.

28. Gao W, DECODE Study Group. Does the constellation of risk factors with and without abdominal adiposity associate with different cardiovascular mortality risk? Int J Obes 2008;32(5):757-762.

29. Grundy SM, Cleeman JI, Daniels SR, et al. American Heart Association; National Heart, Lung, and Blood Institute. Diagnosis and management of the metabolic syndrome: an American Heart Association/National Heart, Lung, and Blood Institute Scientific Statement. Circulation 2005;112 (17):2735-2752. [PubMed: 16157765]

30. Novo S, Balbarini A, Belch JJ, et al. Guidelines Committee of the International Union of Angiology; Scientific Committee of the International Union of Angiology; Council of Vascular Medicine of the International Union of Angiology. The metabolic syndrome: definition, diagnosis and management. Int Angiol 2008;27(3):220-231. [PubMed: 18506125]

31. Chen K, Lindsey JB, Khera A, et al. Independent associations between metabolic syndrome, diabetes mellitus and atherosclerosis: observations from the Dallas Heart Study. Diab Vasc Dis Res 2008;5 (2):96-101. [PubMed: 18537096]

32. Wassink AM, Van Der Graaf Y, Soedamah-Muthu SS, Spiering W, Visseren FLJ, Smart Study Group. Metabolic syndrome and incidence of type 2 diabetes in patients with manifest vascular disease. Diab Vasc Dis Res 2008;5(2):114-122. [PubMed: 18537099]

33. Wannamethee SG, Shaper AG, Whincup PH. Modifiable lifestyle factors and the metabolic syndrome in older men: Effects of lifestyle changes. J Am Geriatr Soc 2006;54(12):1909-1914. [PubMed: 17198498]

34. Ilanne-Parikka P, Eriksson JG, Lindström J, et al. Finnish Diabetes Prevention Study Group. Effect of lifestyle intervention on the occurrence of metabolic syndrome and its components in the Finnish Diabetes Prevention Study. Diabetes Care 2008;31(4):805-807. [PubMed: 18184907]

35. Phelan S, Wadden TA, Berkowitz RI, et al. Impact of weight loss on the metabolic syndrome. Int J Obes 2007;31:1442-1448. 
36. Calle EE, Rodriguez C, Walker-Thurmond K, Thun MJ. Overweight, obesity, and mortality from cancer in a prospectively studied cohort of U.S. adults. N Engl J Med 2003;348(17):1625-1638. [PubMed: 12711737]

37. Reeves GK, Pirie K, Beral V, Green J, Spencer E, Bull D, Million Women Study Collaboration. Cancer incidence and mortality in relation to body mass index in the Million Women Study: cohort study. BMJ 2007;335(7630):1134. [PubMed: 17986716]

38. Wright ME, Chang SC, Schatzkin A, et al. Prospective study of adiposity and weight change in relation to prostate cancer incidence and mortality. Cancer 2007;109(4):675-684. [PubMed: 17211863]

39. Rodriguez C, Freedland SJ, Deka A, et al. Body mass index, weight change, and risk of prostate cancer in the Cancer Prevention Study II Nutrition Cohort. Cancer Epidemiol Biomarkers Prev 2007;16(1):63-69. [PubMed: 17179486]

40. Thygesen LC, Grønbaek M, Johansen C, Fuchs CS, Willett WC, Giovannucci E. Prospective weight change and colon cancer risk in male US health professionals. Int J Cancer 2008;123(5):1160-1165. [PubMed: 18546286]

41. Pischon T, Lahmann PH, Boeing $\mathrm{H}$, et al. Body size and risk of colon and rectal cancer in the European Prospective Investigation Into Cancer and Nutrition (EPIC). J Natl Cancer Inst 2006;98(13):920931. [PubMed: 16818856]

42. Pischon T, Lahmann PH, Boeing $\mathrm{H}$, et al. Body size and risk of renal cell carcinoma in the European Prospective Investigation into Cancer and Nutrition (EPIC). Int J Cancer 2006;118(3):728-738. [PubMed: 16094628]

43. Sharma L, Chang A. Overweight: advancing our understanding of its impact on the knee and the hip. Ann Rheum Dis 2007;66(2):141-142. [PubMed: 17242017]

44. Lievense AM, Bierma-Zeinstra SM, Verhagen AP, van Baar ME, Verhaar JA, Koes BW. Influence of obesity on the development of osteoarthritis of the hip: a systematic review. Rheumatology (Oxford) 2002;41(10):1155-1162. [PubMed: 12364636]

45. Reijman M, Pols HA, Bergink AP, et al. Body mass index associated with onset and progression of osteoarthritis of the knee but not of the hip: the Rotterdam Study. Ann Rheum Dis 2007;66(2):158162. [PubMed: 16837490]

46. Hart DJ, Doyle DV, Spector TD. Incidence and risk factors for radiographic knee osteoarthritis in middle-aged women: the Chingford Study. Arthritis Rheum 1999;42(1):17-24. [PubMed: 9920009]

47. Felson DT, Zhang Y, Hannan MT, et al. Risk factors for incident radiographic knee osteoarthritis in the elderly: the Framingham Study. Arthritis Rheum 1997;40(4):728-733. [PubMed: 9125257]

48. Creamer P, Lethbridge-Cejku M, Hochberg MC. Factors associated with functional impairment in symptomatic knee osteoarthritis. Rheumatology 2000;39(5):490-496. [PubMed: 10852978]

49. Jinks C, Jordan K, Croft P. Disabling knee pain - another consequence of obesity: results from a prospective cohort study. BMC Public Health 2006;6:258. [PubMed: 17052337]

50. Marks R. Obesity profiles with knee osteoarthritis: correlation with pain, disability, disease progression. Obesity 2007;15(7):1867-1874. [PubMed: 17636106]

51. Sutbeyaz ST, Sezer N, Koseoglu BF, Ibrahimoglu F, Tekin D. Influence of knee, osteoarthritis on exercise capacity and quality of life in obese adults. Obesity 2007;15(8):2071-2076. [PubMed: 17712125]

52. Tukker A, Visscher T, Picavet H. Overweight and health problems of the lower extremities: osteoarthritis, pain and disability. Public Health Nutr 2009;12(3):359-368. [PubMed: 18426630]

53. Christensen R, Bartels EM, Astrup A, Bliddal H. Effect of weight reduction in obese patients diagnosed with knee osteoarthritis: a systematic review and meta-analysis. Ann Rheum Dis 2007;66 (4):433-439. [PubMed: 17204567]

54. Fransen M. Dietary weight loss and exercise for obese adults with knee osteoarthritis: modest weight loss targets, mild exercise, modest effects. Arthritis Rheum 2004;50(5):1366-1369. [PubMed: 15146405]

55. Huang MH, Chen CH, Chen TW, Weng MC, Wang WT, Wang YL. The effects of weight reduction on the rehabilitation of patients with knee osteoarthritis and obesity. Arthritis Care Res 2000;13(6): 398-405. [PubMed: 14635316] 
56. Messier SP, Loeser RF, Miller GD, et al. Exercise and dietary weight loss in overweight and obese older adults with knee osteoarthritis: the Arthritis, Diet, and Activity Promotion Trial. Arthritis Rheum 2004;50(5):1501-1510. [PubMed: 15146420]

57. Miller GD, Nicklas BJ, Davis C, Loeser RF, Lenchik L, Messier SP. Intensive weight loss program improves physical function in older obese adults with knee osteoarthritis. Obesity 2006;14(7):12191230. [PubMed: 16899803]

58. van Gool CH, Penninx BW, Kempen GI, et al. Effects of exercise adherence on physical function among overweight older adults with knee osteoarthritis. Arthritis Rheum 2005;53(1):24-32. [PubMed: 15696558]

59. Liu B, Balkwill A, Spencer E, Beral V, Million Women Study Collaborators. Relationship between body mass index and length of hospital stay for gallbladder disease. J Public Health (Oxf) 2008;30 (2):161-166. [PubMed: 18308742]

60. Tsai CJ, Leitzmann MF, Willett WC, Giovannucci EL. Prospective study of abdominal adiposity and gallstone disease in US men. Am J Clin Nutr 2004;80(1):38-44. [PubMed: 15213025]

61. Katsika D, Tuvblad C, Einarsson C, Lichtenstein P, Marschall HU. Body mass index, alcohol, tobacco and symptomatic gallstone disease: a Swedish twin study. J Intern Med 2007;262(5):581-587. [PubMed: 17908165]

62. Al Mofleh IA. Severe acute pancreatitis: pathogenetic aspects and prognostic factors. World J Gastroenterol 2008;14(5):675-684. [PubMed: 18205255]

63. De Waele B, Vanmierlo B, Van Nieuwenhove Y, Delvaux G. Impact of body overweight and class I, II and III obesity on the outcome of acute biliary pancreatitis. Pancreas 2006;32(4):343-345. [PubMed: 16670615]

64. Martínez J, Johnson CD, Sánchez-Payá J, de Madaria E, Robles-Díaz G, Pérez-Mateo M. Obesity is a definitive risk factor of severity and mortality in acute pancreatitis: an updated meta-analysis. Pancreatology 2006;6(3):206-209. [PubMed: 16549939]

65. Papachristou GI, Papachristou DJ, Avula H, Slivka A, Whitcomb DC. Obesity increases the severity of acute pancreatitis: performance of APACHE-O score and correlation with the inflammatory response. Pancreatology 2006;6(4):279-285. [PubMed: 16636600]

66. Preiss D, Sattar N. Non-alcoholic fatty liver disease: an overview of prevalence, diagnosis, pathogenesis and treatment considerations. Clin Sci (Lond) 2008;115(5):141-150. [PubMed: 18662168]

67. Targher G, Arcaro G. Non-alcoholic fatty liver disease and increased risk of cardiovascular disease. Atherosclerosis 2007;191(2):235-240. [PubMed: 16970951]

68. Riquelme A, Arrese M, Soza A, et al. Non-alcoholic fatty liver disease and its association with obesity, insulin resistance and increased serum levels of C-reactive protein in Hispanics. Liver Int 2009;29 (1):82-88. [PubMed: 18647235]

69. Zelber-Sagi S, Nitzan-Kaluski D, Halpern Z, Oren R. Prevalence of primary non-alcoholic fatty liver disease in a population-based study and its association with biochemical and anthropometric measures. Liver Int 2006;26(7):856-863. [PubMed: 16911469]

70. Church TS, Kuk JL, Ross R, Priest EL, Biltoft E, Blair SN. Association of cardiorespiratory fitness, body mass index, and waist circumference to nonalcoholic fatty liver disease. Gastroenterology 2006;130(7):2023-2030. [PubMed: 16762625]

71. Adams LA, Angulo P. Treatment of non-alcoholic fatty liver disease. Postgrad Med J 2006;82(967): 315-322. [PubMed: 16679470]

72. Duvnjak M, Lerotić I, Barsić N, Tomasić V, Virović Jukić L, Velagić V. Pathogenesis and management issues for non-alcoholic fatty liver disease. World J Gastroenterol 2007;13(34):4539_ 4550. [PubMed: 17729403]

73. Haslam DW, James WP. Obesity. Lancet 2005;366(9492):1197-1209.

74. Pillar G, Shehadeh N. Abdominal fat and sleep apnea: the chicken or the egg? Diabetes Care 2008;31 (suppl 2):S303-S309. [PubMed: 18227501]

75. Resta O, Foschino-Barbaro MP, Legari G, et al. Sleep-related breathing disorders, loud snoring and excessive daytime sleepiness in obese subjects. Int J Obes Relat Metab Disord 2001;25(5):669-675. [PubMed: 11360149] 
76. Peppard PE, Young T, Palta M, Dempsey J, Skatrud J. Longitudinal study of moderate weight change and sleep-disordered breathing. JAMA 2000;284(23):3015-3021. [PubMed: 11122588]

77. Newman AB, Foster G, Givelber R, Nieto FJ, Redline S, Young T. Progression and regression of sleep-disordered breathing with changes in weight: the Sleep Heart Health Study. Arch Intern Med 2005;165(20):2408-2413. [PubMed: 16287771]

78. Grunstein RR, Stenlöf K, Hedner JA, Peltonen M, Karason K, Sjöström L. Two year reduction in sleep apnea symptoms and associated diabetes incidence after weight loss in severe obesity. Sleep 2007;30(6):703-710. [PubMed: 17580591]

79. Petry NM, Barry D, Pietrzak RH, Wagner JA. Overweight and obesity are associated with psychiatric disorders: results from the National Epidemiologic Survey on Alcohol and Related Conditions. Psychosom Med 2008;70(3):288-297. [PubMed: 18378873]

80. Strine TW, Mokdad AH, Dube SR, et al. The association of depression and anxiety with obesity and unhealthy behaviors among community-dwelling US adults. Gen Hosp Psychiatry 2008;30(2):127137. [PubMed: 18291294]

81. Simon GE, Ludman EJ, Linde JA, et al. Association between obesity and depression in middle-aged women. Gen Hosp Psychiatry 2008;30(1):32-39. [PubMed: 18164938]

82. Adams KF, Schatzkin A, Harris TB, et al. Overweight, obesity, and mortality in a large prospective cohort of persons 50 to 71 years old. N Engl J Med 2006;355(8):763-778. [PubMed: 16926275]

83. Flegal KM, Graubard BI, Williamson DF, Gail MH. Cause-specific excess deaths associated with underweight, overweight, and obesity. JAMA 2007;298(17):2028-2037. [PubMed: 17986696]

84. Manson JE, Willett WC, Stampfer MJ, et al. Body weight and mortality among women. N Engl J Med 1995;333(11):677-685. [PubMed: 7637744]

85. McTigue K, Larson JC, Valoski A, et al. Mortality and cardiac and vascular outcomes in extremely obese women. JAMA 2006;296(1):79-86. [PubMed: 16820550]

86. Murphy NF, MacIntyre K, Stewart S, Hart CL, Hole D, McMurray JJ. Long-term cardiovascular consequences of obesity: 20-year follow-up of more than 15000 middle-aged men and women (the Renfrew-Paisley study). Eur Heart J 2006;27(1):96-106. [PubMed: 16183687]

87. Stevens J, Cai J, Pamuk ER, Williamson DF, Thun MJ, Wood JL. The effect of age on the association between body-mass index and mortality. N Engl J Med 1998;338(1):1-7. [PubMed: 9414324]

88. Thomas F, Bean K, Pannier B, Oppert JM, Guize L, Benetos A. Cardiovascular mortality in overweight subjects: the key role of associated risk factors. Hypertension 2005;46(4):654-659. [PubMed: 16157786]

89. Yan LL, Daviglus ML, Liu K, et al. Midlife body mass index and hospitalization and mortality in older age. JAMA 2006;295(2):190-198. [PubMed: 16403931]

90. Fontaine KR, Redden DT, Wang C, Westfall AO, Allison DB. Years of life lost due to obesity. JAMA 2003;289(2):187-193. [PubMed: 12517229]

91. Adams TD, Gress RE, Smith SC, et al. Long-term mortality after gastric bypass surgery. N Engl J Med 2007;357(8):753-761. [PubMed: 17715409]

92. Sjöström L, Narbro K, Sjöström CD, et al. Effects of bariatric surgery on mortality in Swedish Obese Subjects. N Engl J Med 2007;357(8):741-752. [PubMed: 17715408]

93. Thompson D, Edelsberg J, Colditz GA, Bird AP, Oster G. Lifetime health and economic consequences of obesity. Arch Intern Med 1999;159(18):2177-2183. [PubMed: 10527295]

94. Muennig P, Lubetkin E, Jia H, Franks P. Gender and the burden of disease attributable to obesity. Am J Public Health 2006;96(9):1662-1668. [PubMed: 16873748] 

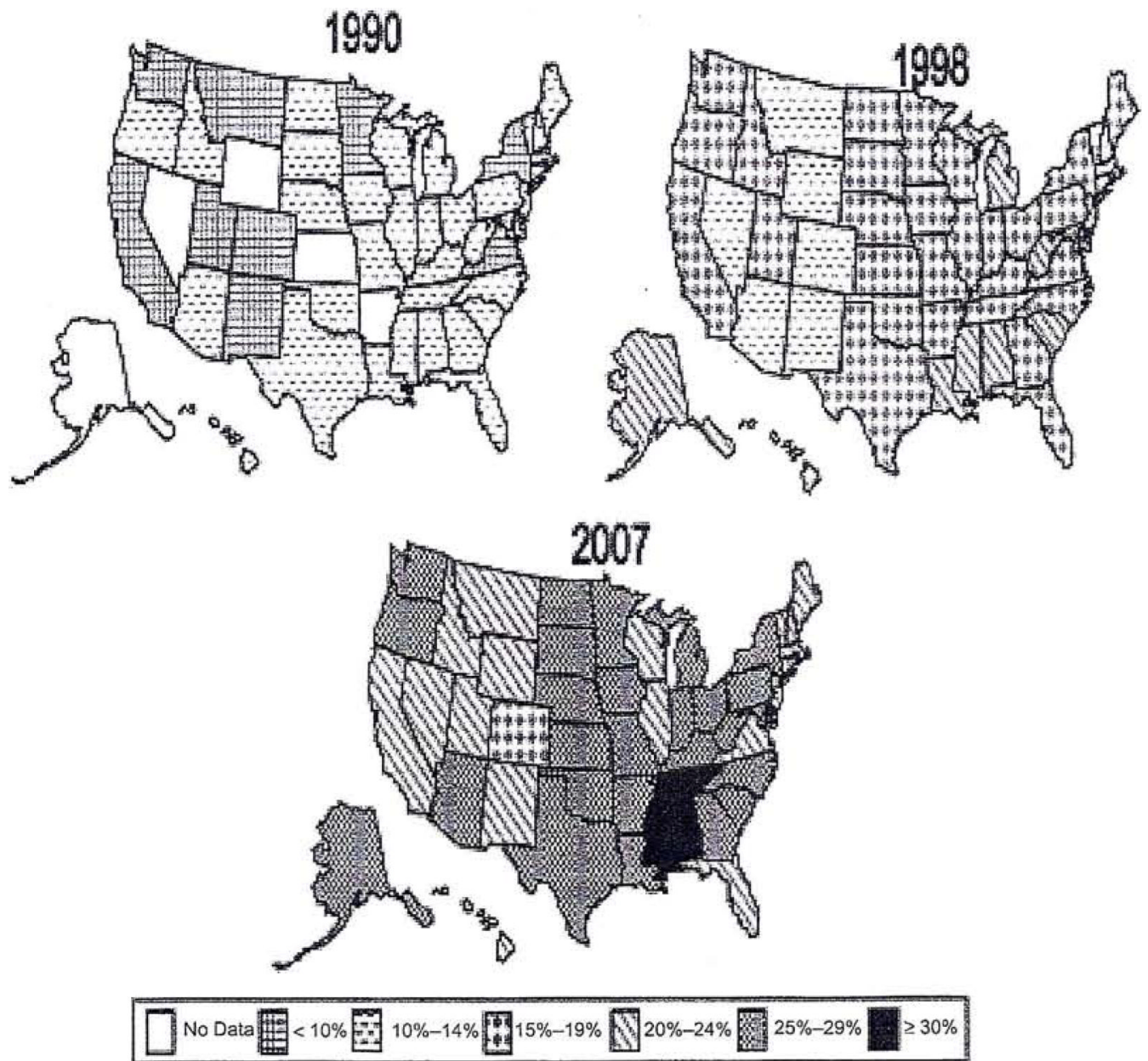

Figure 1.

Trends in obesity among US adults over 17 years (1990-2007). ${ }^{3}$ 

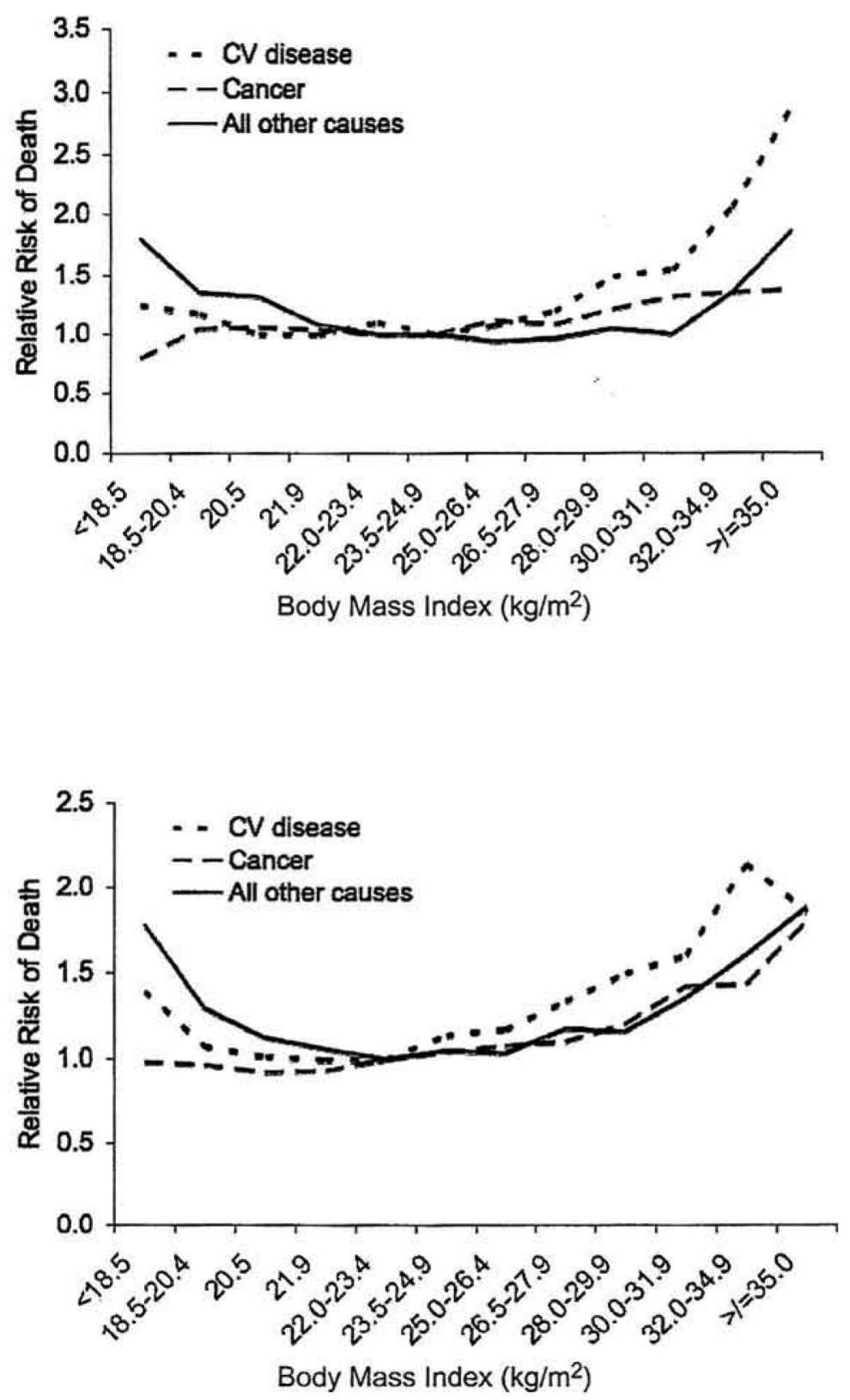

Reproduced with permission. Copyright (C) 1999, Massachusetts Medical Society. All rights reserved."

Figure 2.

Relative risk of death from all causes, CVD, and cancer according to BMI in men (top) and women (bottom). ${ }^{4}$ 


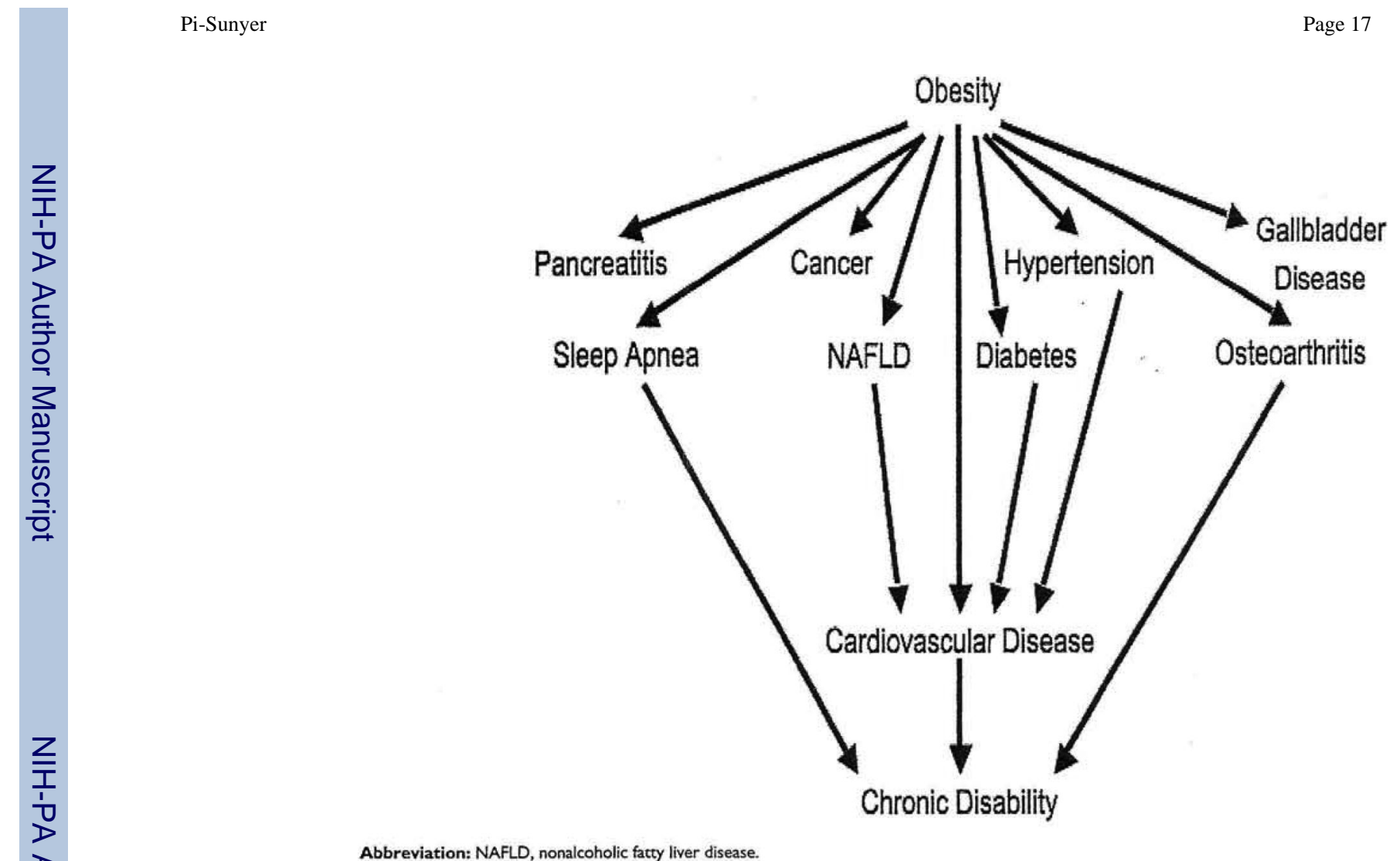

Figure 3.

Association of obesity and important comorbidities. 


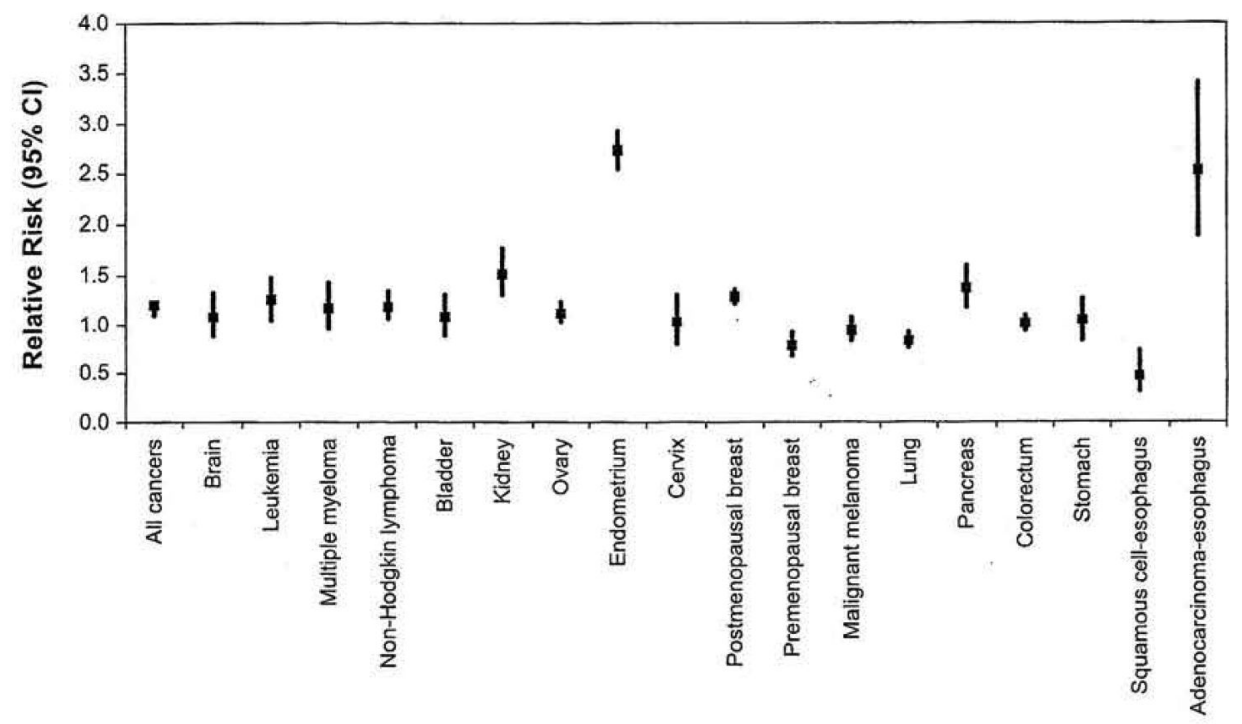

Reproduced with permission from BMJ."

Figure 4.

Relative risk of cancer according to the presence of obesity $\left(\mathrm{BMI} \geq 30 \mathrm{~kg} / \mathrm{m}^{2}\right) \cdot{ }^{37}$ Reference value was 1.0 for participants with a BMI of $22.5-24.9 \mathrm{~kg} / \mathrm{m}^{2}$. 
Table 1

Effect of Obesity on Mortality: A Summary of Controlled Trials

\begin{tabular}{|c|c|c|c|c|}
\hline Reference & Study Population & Endpoints & Weight Categories & Outcomes \\
\hline Flegal $(2007)^{83}$ & $\begin{array}{l}\text { NHANES I, II, III } \\
\text { cohort } 571000 \text { years } \\
\text { of follow-up }\end{array}$ & $\begin{array}{l}\mathrm{CV} \text { mortality, cancer } \\
\text { mortality }\end{array}$ & $\begin{array}{l}\text { Underweight, overweight (BMI } 25-30 \\
\left.\mathrm{~kg} / \mathrm{m}^{2}\right) \text {, obese }\left(\mathrm{BMI} \geq 30 \mathrm{~kg} / \mathrm{m}^{2}\right)\end{array}$ & $\begin{array}{l}\text { Significant } \uparrow \text { in CVD and } \\
\text { obesity-related cancer } \\
\text { mortality }\end{array}$ \\
\hline Manson (1995) 84 & $\begin{array}{l}\text { Nurses' Health } \\
\text { Study } 115195 \\
\text { women, aged } 30-55 \\
\text { years, free of CVD } \\
\text { and cancer at } \\
\text { baseline; 16-year } \\
\text { follow-up }\end{array}$ & $\begin{array}{l}\text { All-cause mortality, } \\
\text { CV mortality, cancer } \\
\text { mortality }\end{array}$ & $\begin{array}{l}\left.\text { Overweight (BMI } 29-31.9 \mathrm{~kg} / \mathrm{m}^{2}\right) \text { Obese } \\
\left(\mathrm{BMI} \geq 32 \mathrm{~kg} / \mathrm{m}^{2}\right)\end{array}$ & $\begin{array}{l}P<0.001, \text { trend for } \uparrow \text { all- } \\
\text { cause mortality; for BMI } \geq \\
32 \mathrm{~kg} / \mathrm{m}^{2} \text { vs }<19 \mathrm{~kg} / \mathrm{m}^{2} . \mathrm{RR} \\
\text { of } C V \text { mortality } 4.1 \text { and } \\
\text { cancer } 2.1\end{array}$ \\
\hline McTigue (2006) 85 & $\begin{array}{l}\text { Women's Health } \\
\text { Initiative } \\
\text { Observational Study } \\
90185 \text { women; mean } \\
\text { follow-up of } 7 \text { years }\end{array}$ & All-cause mortality & $\begin{array}{l}\text { Normal }\left(B M I 18.5-24.9 \mathrm{~kg} / \mathrm{m}^{2}\right) \text { Obese } \\
\left(B M I \geq 30 \mathrm{~kg} / \mathrm{m}^{2}\right)\end{array}$ & $\begin{array}{l}\text { All = cause mortality } \uparrow \\
68.4 / 10000 \text { normal } 84.5 \text { for } \\
\text { obese }\end{array}$ \\
\hline Stevens $(1998)^{87}$ & $\begin{array}{l}\text { ACS Prevention } \\
\text { Study I; } 324000 \\
\text { healthy, never } \\
\text { smoking men and } \\
\text { women; 12-year } \\
\text { follow-up }\end{array}$ & $\begin{array}{l}\text { All-cause mortality, } \\
\text { CV mortality }\end{array}$ & $\begin{array}{l}\text { Overweight (BMI 29-31.9 kg/m²) } \\
\left.\text { Obese (BMI } \geq 32 \mathrm{~kg} / \mathrm{m}^{2}\right)\end{array}$ & $\begin{array}{l}50 \% \uparrow \text { in all-cause mortality } \\
\text { associated with BMI }>27 \mathrm{~kg} / \\
\mathrm{m}^{2} \text { in men aged } 30-84 \text { years } \\
\text { and } \geq 29 \text { in women aged } 30- \\
74 \text { years }\end{array}$ \\
\hline Adams (2006) 82 & $\begin{array}{l}\text { NIH-AARP cohort } \\
527265 \text { men and } \\
\text { women, aged 50-71 } \\
\text { years; } 10 \text {-year } \\
\text { follow-up }\end{array}$ & All-cause mortality & Obese (BMI $30-34.9 \mathrm{~kg} / \mathrm{m}^{2}$ ) & $\begin{array}{l}1.1 \text {-fold } \uparrow \text { in mortality } \\
\text { compared with normal BMI; } \\
\text { obesity }=18 \% \text { of excess } \\
\text { mortality }\end{array}$ \\
\hline Calle $(1999)^{6}$ & $\begin{array}{l}>1 \text { million in ACS } \\
\text { Study II 14-year } \\
\text { follow-up }\end{array}$ & All-cause mortality & Obese (BMI $30-32 \mathrm{~kg} / \mathrm{m}^{2}$ ) & $\begin{array}{l}\text { Among healthy nonsmokers } \\
\text { risk of death } \uparrow 17 \%-32 \%\end{array}$ \\
\hline Fontaine (2003) ${ }^{90}$ & $\begin{array}{l}\text { NHANES cohort } \\
\text { adults aged } 18-85 \\
\text { years }\end{array}$ & Years of life lost & $\begin{array}{l}\text { Low BMI }\left(<17-19 \mathrm{~kg} / \mathrm{m}^{2}\right) \text {, high BMI }(\geq \\
\left.35 \mathrm{~kg} / \mathrm{m}^{2}\right)\end{array}$ & $\begin{array}{l}\text { Years of life lost were } 1-9 \text { for } \\
\text { low BMI vs } 9-13 \text { for BMI } \geq \\
35 \mathrm{~kg} / \mathrm{m}^{2}\end{array}$ \\
\hline Yan (2006) 89 & $\begin{array}{l}17643 \text { men and } \\
\text { women aged 31-64 } \\
\text { years; no risk factors } \\
\text { at baseline }\end{array}$ & $\begin{array}{l}\text { Mortality from CHD, } \\
\text { CVD, or diabetes }\end{array}$ & Obese (BMI $\left.\geq 30 \mathrm{~kg} / \mathrm{m}^{2}\right)$ & $\begin{array}{l}\uparrow \text { risk of hospitalization and } \\
\text { mortality from CHD, CV } \\
\text { disease, and diabetes vs } \\
\text { normal weight }\end{array}$ \\
\hline Thomas (2006) ${ }^{88}$ & $\begin{array}{l}243000 \text { men and } \\
\text { women aged 18-95 } \\
\text { years, followed for } \\
\text { up to } 25 \text { years }\end{array}$ & $\begin{array}{l}\text { Total mortality, CVD } \\
\text { mortality }\end{array}$ & Obese (BMI $\left.\geq 30 \mathrm{~kg} / \mathrm{m}^{2}\right)$ & $\begin{array}{l}\text { Total and CVD mortality was } \\
>2 \text {-fold higher among obese } \\
\text { vs nonobese }\end{array}$ \\
\hline
\end{tabular}

Abbreviations: ACS, acute coronory syndrome; CHD, coronary heart disease; CV, cardiovascular; CVD, cardiovascular disease; NHANES, National Health and Nutrition Examination Survey; RR, relative risk. 